\title{
The U se of Social Media and its Reflection on the Political Participation of Youth
}

\section{Shadia Rabie Zaky (PhD)}

Associate Professor of Community Organization

Higher Institute of Social Work in Cairo

\section{Ahmed Mostafa Mohamed Taha (PhD)}

Associate Professor of Community Organization

Higher Institute of Social Work in Cairo 



\section{Abstract:}

The study aims to identify the nature of the impact of social media on university youth and its reflection on their political participation and determining the relationship between youth use of social media and its reflection on their political participation. This study belongs to the realm of descriptive analytical studies. The study relies on sample social survey method for the four teams of university students (the Higher Institute of Social Work). The current research was based on a questionnaire on "social media and youth political participation". A stratified random sample representing the number of the institute's students was selected, amounting to (115) male and female students at a rate of $(1 \%)$ of the study population. The study examines the nature of the impact of social media on university youth and its reflection on their political participation by providing social networking sites, a space to express opinion freely without a security threat. The study finds that there are statistically significant differences at level $(\alpha=0.05)$ between the averages of the impact of social media on youth's political participation, with the gender variable in favor of males.

Keywords: Social media - political participation - youth

\section{Introduction}

Many studies suggest that there is a direct relation between the real participatory power of young people and their readiness to get involved in the political process and public policies. This can mean all sorts of participation, such as voting rights from a lower age, participation in the creation of public spaces in urban areas and rural development, involvement in ecological programming and stronger recognition of the consumer status of young people, and hence their contribution to the economy (Jamieson, 2020, p.5).

Often accused of being part of the generation of individualism and apathy, numerous young people are now turning again towards political and social commitment, thanks to the alter-globalization movement. This new activist generation has been profoundly marked by our era and cannot be understood without being situated in a wider process of social transformation. Mobilized in the public arena, these young people have renounced neither their individualism nor their deep disillusionment with the traditional structures, institutions, and actors of social and political life. On the contrary, they show us that these essential traits of the contemporary population are not necessarily leading to apathy or to a retreat to the private sphere. They can also be the basis for new forms of commitment and for new cultures of political participation (Pleyers, 2020, p.133). 
There is no doubt that changes in methods and weapons could alter the nature of conflict. Just as machineguns, tanks, and aircraft changed the nature of conflicts, so did the telegraph, radio, television, and eventually the internet. The advances in the information world today, specifically with the advent of social media, may prove as profound as any of these inventions (Mayfield, 2001, p.79).

Youth's relationship to social media addiction is a big topic today. Youths are among the biggest consumers of social media as statistics indicate that $92 \%$ of youths go online daily, $24 \%$ say they go online "almost constantly", $76 \%$ use social media $81 \%$ of older youths, $68 \%$ of teens ages (13 and 14).,71\% of youths use Facebook, 52\% use Instagram, $41 \%$ use Snapchat, $33 \%$ use Twitter, and 14\% use Tumblr (Pew Research Center, 2017).

Social media represents an important part of youth users' lives. Youth users have a large followership of other youth or groups in addition to their appeal for information gathering and dissemination, such as young people's everyday political conversations as expressions of political citizenship in social media (Harris and Wyn, 2009, p.327).

Looking at previous studies and research, Auskalniene's study indicates (2012) that social media are more and more involved into the everyday communication practice and become one of the major political communication channels, particularly focusing on the involvement of young people in the decision-making process. Fundamental societal transformations, undoubtedly facilitated by new technologies, are changing the way we interact, communicate, produce and exchange knowledge. Zúñiga, et al. (2014) clarifies the effect of using social media for social interaction in fostering political expression and participation processes. Results indicate that social media news use has direct effects on offline political participation and indirect effects on offline and online political participation mediated via political expression. Furthermore, social media use for social interaction does not have direct influence on people's political engagement, but rather an indirect effect by means of citizens expressing themselves politically.

Loader's et al. (2014) research highlights the role played by social media use in the processes through which young people become politically engaged. Notably, our results also provide reasons to be optimistic concerning the overall influence of this popular new form of digital media on longstanding patterns of political inequality. The study of Hayes \& Carr (2014) indicates how social media may uniquely isolate and test communicative principles to advance our understanding of human-human and human-computer interaction. 
Vromen et al. (2015) study's findings suggest that understanding young people's political engagement reveals important differences that are evident in young people's citizenship norms: between the dutiful allegiance to formal politics and their preference for online self-actualizing and discursive forms of political engagement and organizing. The ways in which political information is broadcast, shared and talked about on social media by engaged young people, demonstrate the importance of communicative forms of action for the future of political engagement. Schuster's (2017) study examines the impact of young women's online activism on the visibility of feminist engagement. The study identifies a generational divide in the ways these women participated in feminist activities and argues that online activism is a key form of participation for many young women. Since online activism is only visible to those who use it, this form of participation hides many young women's activities from the wider public and from politically active women of older generations.

Allaste \& Cairns's (2016) study explores different dimensions of participation, providing examples of how politics is practiced by young people in a society that has undergone a relatively recent and substantial social, economic, and political transformation: the shift from being an integral part of the Soviet Union to full membership of the European Union. This transition is reflected in the changing patterns of activism among Estonian youth and the nature of the issues with which they engage with participation that is influenced by, on the one hand, the legacies of the communist period and, on the other, the challenge of living in contemporary Europe. Arshad \& Khurram's (2020) study investigates the association of quality information provided by a government agency on social media and citizen's online political participation. The results reveal that the agency's provision of quality information on social media was significantly related to perceived transparency, trust in agency, perceived responsiveness, and citizens' online political participation. Moreover, the results show that perceived transparency mediates the relationship between the agency's provision of quality information on social media and citizen's trust in the agency.

In recent years, news reports have frequently portrayed social media such as Facebook and Twitter as playing a key role in social upheavals and political protests in countries such as Iran and Egypt. (Grossman, 2009 and Shane, 2011). In Iran, using e-mail messages to increase political participation of youths has been found to be positive (Rahim, 2003). 
Recent developments suggest a strong relationship between social media use and political engagement and raise questions about the potential for social media to help stem or even reverse patterns of political inequality (Loader, Xenos \& Vromen, 2014, p.151).

\section{Study problem}

Social media has affected how people interact socially. Through social media, people can exchange photos and videos, share news stories, post their thoughts on blogs, and participate in online discussions. The impact of social media can be seen in the social and economic effects. Some believe the internet is making people more isolated, while others hope it will increase democracy (Dewing, 2010, p.13).

Social media is pervasive in the lives of young people; politically engaged young people integrate social media use into their existing organizations and political communications. The problem here is how young people from a broad range of existing political and civic groups use social media for sharing information, mobilization and, increasingly, as a means to redefine political action and political spaces (Vromen, Xenos \& Loader, 2015, p. 81).

This political participation reinforces political behavior. The effects of being politically engaged on political interest, efficacy, confidence, and norms of citizenship are clearly stronger than the effects of these attitudes on participation. (Quintelier \& van Deth, 2014, p.153)

Based on the previous indicators, the problem of the current research is determined in an attempt to answer the following main question: What is the impact of social media use on the political participation of youth?

\section{Theoretical Guidelines of the Research}

\section{1-Network Theory "Manuel Castells":}

The postulates on which the theory is based:

C- Societies live and die under the banner of rationality and production, that is, they show the power of labor and the state of technical knowledge, and that is, there is an arrangement at the level of the possible techniques of production.

D- History has moved from a time that passes to a time that will come, as modern technologies have not given time the same meaning that it had before; as the distances become close, and then we are in front of (the fluidity of time), time is no longer circular, and the idea of recalling history is no longer possible, because history does not repeat its events (Robinson, 1953, pp. 81-106) 
The network society is one in which networks shape its social structures, as these networks are based on communication technologies. Through the nature of the social structure, the organizational hierarchies of human beings can be understood as manifested in experiences, knowledge, arts, language, housing, clothing, food, medicine, standards, production, distribution, relationship to others, and the power expressed in meaningful communication through culture.

If the network is a set of interlocking nodes, then the code is the point at which the two curves of this network intersect. Hence, the network has no center and no codes. The codes may vary among themselves in relation to the network. However, these codes increase the importance of the network by absorbing more information associated with it and processing it more efficiently. The relative importance of the code does not stem from specific technical parameters, but rather from its ability to contribute to the achievement of network goals.

However, all of the code in a network is essential to normal network performance. When code becomes redundant, or useless/inconvenient, networks are compelled and inclined to reconfigure themselves, delete some code, and add new ones. Hence, the function of ciphers is that they exist and act as active elements in networks only, that is, the network is the unit / kernel, not the code (Castells, 2004).

\section{Points of benefit from "Network Theory" in this study:}

In the context of the present study, this theory explains that the network is the new social structure of the information age, the age of the networked society consisting of networks of production, power, and experience, where these networks play their role in building a virtual culture within the framework of information flows, bypassing the concept of time and space. It also explains the use of social networks to support volunteerism among young people through the interaction between humans and the network, which represents one of the pillars of building modern societies.

\section{Research Goals}

Based on the main research question, the research objectives can be defined as follows:

- Detecting the extent of the spread of social media among university youth and its use in political participation.

- Identifying the nature of the impact of social media on university youth and its reflection on their political participation.

- Determining the relationship between youth use of social media and its reflection on their political participation. 


\section{Study hypotheses}

The study seeks to test the validity of the following hypotheses:

1 - There are statistically significant differences at level $(\alpha=0.05)$ between the means of the impact of social media on youth's political participation, due to the gender variable.

2 - There are statistically significant differences at the level $(\alpha=0.05)$ between the means of the impact of social media on youth's political participation, due to the study band.

3- There are statistically significant differences at the level $(\alpha=0.05)$ between the means of the impact of social media on youth's political participation due to the variable of youth's political affiliation.

\section{The concepts}

\section{Political participation:}

That participation's meaning is intuitively obvious and unproblematic. A recent author even begins his explication of the concept with the confident assertion "there is no problem with defining the meaning of the word 'participation" as dictionary definitions should suffice.

The two concepts of politics and participation represent two contrasting forms of rationality, both equally plausible and equally a part of our tradition, language, and practice of politics. This investigation does not aim to vote one concept up and the other down; both are rational and in their own ways. The concept of participation as interaction has been slighted or ignored, and thus deserves more balanced attention in our political practices and scientific investigations.

People's mobilizing within organizations is meant to influence decision-making and power centers, targeting a wide array of issues clamoring for the maintenance of cultural activities, to anti-globalization demonstrations (Gauthier, 2010, p.265).

Social media: "refers to the wide range of internet-based and mobile services that allow users to participate in online exchanges, contribute user-created content, or join online communities" (Dewing, 2010, p.1).

More specifically, the term social media refers to the use of web-based and mobile technologies that are commonly used for interaction and communication within networks (Li, Barnett, Goodman \& Wasserman and Kemper, 2013).

Youth:"The concept of youth is determined by the age groups (15-24), and the exact definition of youth concepts varies according to many factors, including cultural, family status, rural or urban differences, and many different factors that contribute to defining this concept" (Seltzer, 1984, p.7). 
Or it "can be defined on the basis of the individual bearing responsibility, as the young man does not become fully mature unless he takes responsibility, and accordingly the beginning of this stage in some societies is determined by the ability to practice what adults do" (Matza\& Fares, 1984, p.129).

\section{Operational Concept of "youth political participation through the means of communication":}

Youth mobilizing within organizations is meant to influence decisionmaking and power centers, through the wide range of internet-based and mobile services that allow users to participate in online exchanges, contribute user-created content, or join online communities, targeting a wide array of issues clamoring for the maintenance of cultural activities.

\section{Methodology}

This study belongs to the type of descriptive analytical studies; it aims to identify the use of social media and its reflection on the political participation of young people.

The study relied on sample social survey method for the four teams of university students (The Higher Institute of Social Work).

\section{Tools}

The current research was based on a questionnaire on "social media and youth political participation" applied on youth in the higher education stage.

\section{Design of the study questionnaire}

The study questionnaire was prepared, designed, and developed to collect data as follows:

- Reviewing the theoretical framework related to the variables of the current study, such as social media and political participation.

- A review of research, studies and scientific articles that researched the use of social media by young people and its reflection on their political participation, such as Auskalniene's (2012) study about youth and their involvement in social media, and Schuster's study (2017) about social media and young women's political participation.

- The study's tool consists of three axes:

1- The first section includes: data related to describing the characteristics of youth who represent the study community.

2- The second axis measures the political participation of young people through: data on their political affiliation, loyalty, and political knowledge.

3- The third axis measures the impact of social media on the political participation of young people. 
Determination of questionnaire levels: The questionnaire was constructed and divided into categories so that the results of the study could be reached using the arithmetic mean, where the data was encoded and entered into the computer to determine the length of the triple questionnaire cells (minimum and upper limits). The range was calculated $=$ the largest value - the lowest value $(3-1=2)$. They were divided by the number of the questionnaire's cells to obtain the corrected cell length $(2 / 3=0.67)$. This value was then added to the lowest value in the questionnaire or the beginning of the questionnaire, which is the correct one to determine the upper limit of this cell. Thus, cell length is as follows:

Table (1) Questionnaire Levels:

\begin{tabular}{|l|c||}
\hline $\begin{array}{l}\text { If the average value of a phrase or dimension varies between } 1 \text { - less than } \\
1.67\end{array}$ & low level \\
\hline \hline $\begin{array}{l}\text { If the average value of a phrase or dimension varies between } 1.67-\text { less } \\
\text { than } 2.35\end{array}$ & $\begin{array}{c}\text { middle } \\
\text { level }\end{array}$ \\
\hline \hline If the average value of a phrase or dimension varies between $2.35-3$ & High level \\
\hline
\end{tabular}

\section{Reliability}

The reliability and validity of the tool means that "it yielded the same results with repeated use". The sincerity and constancy of the questionnaire was calculated using the "SPSS" program by the coefficient of "Alpha - Cronbach", where the level of "0.799" is a high value that is positive and acceptable for study purposes.

\section{Sample}

The study population was represented by the students of the four teams at The Higher Institute of Social Work in Cairo, and their number reached (11521) male and female students in the academic year 2020/2021.

A stratified random sample representing the number of the institute's students was selected, amounting to (115) male and female students at a rate of $(1 \%)$ of the study population. 


\section{Results}

Description of the social characteristics of youth in the study community:

Table (2) Distribution of youth according to their social characteristics

\begin{tabular}{|c|c|c|c|}
\hline \multirow{2}{*}{\multicolumn{2}{|c|}{ Variables }} & \multicolumn{2}{|c|}{ youth $(\mathrm{N}=115)$} \\
\hline & & $* \mathrm{~m}$ & S.D* \\
\hline \multicolumn{2}{|l|}{ Mean years of age of Youth } & 18.254 & 0.321 \\
\hline \multicolumn{2}{|l|}{ Mean number of family members } & 4.321 & 0.354 \\
\hline Variables & Responses & $\mathrm{F}^{*}$ & $\%$ \\
\hline \multirow{2}{*}{ Gender } & male & 64 & 55.7 \\
\hline & female & 51 & 44.3 \\
\hline \multirow{4}{*}{ Study band } & first band & 21 & 18.3 \\
\hline & second band & 29 & 25.2 \\
\hline & Third band & 30 & 26.1 \\
\hline & Fourth band & 35 & 30.4 \\
\hline \multirow{6}{*}{ Most used social media ${ }^{*()}$} & Facebook & 98 & 85.2 \\
\hline & Twitter & 64 & 55.7 \\
\hline & $\begin{array}{l}\text { WhatsApp } \\
\end{array}$ & 94 & 81.7 \\
\hline & Messenger & 71 & 61.7 \\
\hline & Instagram & 41 & 35.7 \\
\hline & telegram & 31 & 27.0 \\
\hline \multirow{3}{*}{ family income level } & low level & 22 & 19.1 \\
\hline & middle level & 64 & 55.7 \\
\hline & high level & 29 & 25.2 \\
\hline \multirow{4}{*}{ political affiliation } & party affiliation & 39 & 33.9 \\
\hline & independent & 40 & 34.8 \\
\hline & affiliation Left-wing opposition & 21 & 18.3 \\
\hline & There is no political affiliation & 15 & 13.0 \\
\hline \multirow{3}{*}{ Social media usage tools ${ }^{(*)}$} & mobile phone & 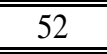 & $4 \quad 45.2$ \\
\hline & personal computer & 31 & 27.0 \\
\hline & the two together & 32 & 27.8 \\
\hline \multirow{4}{*}{ Rate Daily use of social media } & less than an hour & 18 & 15.7 \\
\hline & From an hour to less than two hours & 21 & 18.3 \\
\hline & $\begin{array}{l}\text { From two hours to less than four hours } \\
\end{array}$ & 41 & 35.7 \\
\hline & more than four hours & 35 & 30.4 \\
\hline
\end{tabular}

The results of the table indicate that the mean age of youth (18) years reached the mean number of family members (4) individuals. The proportion of males was (55.7\%), while the proportion of females reached $(44.3 \%)$. The study results indicate that the majority of young people belong to the fourth year by $(30.4 \%)$, followed by those who belong to third year by $(26.1 \%)$, followed by 
those from the second year by $(25.2 \%)$, followed by those from the first year by (18.3\%). Facebook came as the most used social media website by $(85.2 \%)$, followed by WhatsApp $(81.7 \%)$, followed by Messenger $(61.7 \%)$, followed by Twitter (55.7\%), followed by Instagram (35.7\%), finally came Telegram (27.0\%). However, regarding family income level, the majority of the economic level came to middle-income families by $(55.7 \%)$, followed by high-income families $(25.2 \%)$, followed by low-income families (19.1\%). The results of the table indicate that the political affiliation of youth is represented the majority of them being independent by (34.8\%), followed by belonging to parties by $(34.8 \%)$, followed by affiliation to left-wing opposition by (18.3\%), finally came those with no political affiliation by $(13.0 \%)$. Social media usage tools are represented in mobile phone by $(45.2 \%)$, followed by each of a mobile phone and personal computer by $(27.8 \%)$, a personal computer came in last by $(27.0 \%)$. The average daily use of youth to social media ranges from two hours to less than four hours by $(35.7 \%)$, followed by more than four hours by $(30.4 \%)$, followed by from an hour to less than two hours by $(18.3 \%)$, and finally less than an hour by $(15.7 \%)$.

The nature of the impact of social media on university youth and its reflection on their political participation:

Table (3) Distribution of youth according to the nature of the impact of social media on their political participation.

\begin{tabular}{|c|c|c|c|c|c|}
\hline $\begin{array}{l}\text { nature of the impact of social media } \\
\qquad(\mathrm{N}=115)\end{array}$ & $\begin{array}{l}\text { weighted } \\
\text { total }\end{array}$ & mean & $\begin{array}{l}\text { weighted } \\
\text { ratio }\end{array}$ & S. d & $\begin{array}{l}\text { Phrase } \\
\text { value }\end{array}$ \\
\hline $\begin{array}{l}\text { Social media is my primary source of } \\
\text { information. }\end{array}$ & 292 & 2.54 & 84.64 & 0.149 & high \\
\hline $\begin{array}{l}\text { The information provided by social } \\
\text { networking sites is predominantly } \\
\text { political. }\end{array}$ & 261 & 2.27 & 75.65 & 0.140 & medium \\
\hline $\begin{array}{l}\text { Social media contribute to spreading } \\
\text { rumors and inciting strife. }\end{array}$ & 256 & 2.23 & 74.20 & 0.139 & medium \\
\hline $\begin{array}{l}\text { Social media has a role in promoting } \\
\text { political knowledge. }\end{array}$ & 279 & 2.43 & 80.87 & 0.145 & high \\
\hline $\begin{array}{l}\text { I trust the information I get from } \\
\text { social media. }\end{array}$ & 253 & 2.20 & 73.33 & 0.138 & medium \\
\hline $\begin{array}{l}\text { Provide Social networking sites a } \\
\text { space to express opinion freely } \\
\text { without a security threat. }\end{array}$ & 294 & 2.56 & 85.22 & 0.149 & high \\
\hline The general value of the dimension & 1635 & 2.37 & 78.99 & 0.352 & high \\
\hline
\end{tabular}


The results of the table indicate that the general value of the indicator was high with an arithmetic mean of (2.37) by (78.99\%). The nature of the impact of social media on university youth and its reflection on their political participation is represented by: social networking sites providing a space to express opinion freely without a security threat by $(85.22 \%)$, followed by social media is my primary source of information $(84.64 \%)$, followed by social media has a role in promoting political knowledge $(80.87 \%)$, followed by the information provided by social networking sites is predominantly political $(75.65 \%)$, followed by social media contributes to spreading rumors and inciting strife $(74.20 \%)$, finally came their confidence in information received from social media $(73.33 \%)$.

The extent of the spread of social media among university youth and its use in political participation.

Table (4) Distribution of youth according to the extent of the prevalence and use of social media between in political participation among them.

\begin{tabular}{|c|c|c|c|c|c|}
\hline $\begin{array}{l}\text { the spread and use of social media } \\
\text { between youth }(\mathrm{N}=115)\end{array}$ & $\begin{array}{l}\text { weighted } \\
\text { total }\end{array}$ & mean & $\begin{array}{l}\text { weighted } \\
\text { ratio }\end{array}$ & S. d & $\begin{array}{l}\text { Phrase } \\
\text { value }\end{array}$ \\
\hline $\begin{array}{l}\text { I share in party rallies and symposia } \\
\text { that are announced on social media. }\end{array}$ & 259 & 2.25 & 75.07 & 0.140 & medium \\
\hline $\begin{array}{l}\text { In the event of an election, I know } \\
\text { about it through social media. }\end{array}$ & 258 & 2.24 & 74.78 & 0.140 & medium \\
\hline $\begin{array}{l}\text { I always take part in the } \\
\text { parliamentary elections }\end{array}$ & 248 & 2.16 & 71.88 & 0.137 & medium \\
\hline $\begin{array}{l}\text { Fear of harm and security problems } \\
\text { are the reason why I stay away from } \\
\text { political participation. }\end{array}$ & 227 & 1.97 & 65.80 & 0.131 & medium \\
\hline $\begin{array}{l}\text { I accept criticism from others when } \\
\text { discussing political matters }\end{array}$ & 267 & 2.32 & 77.39 & 0.142 & medium \\
\hline $\begin{array}{l}\text { I always put forward the opinion of } \\
\text { the politician on social media. }\end{array}$ & 271 & 2.36 & 78.55 & 0.143 & high \\
\hline The general value of the dimension & 1530 & 2.22 & 73.91 & 0.340 & medium \\
\hline
\end{tabular}

The results of the table indicate that the general value of the indicator was medium with an arithmetic mean of (2.22) by (73.91\%). The extent of the prevalence of social media among university youth and its use in political participation is represented by: I always put forward the opinion of the politician on social media by $(78.55 \%)$, followed by accepting criticism from others when discussing political matters by $(77.39 \%)$, followed by sharing in party rallies and symposia that are announced on social media by $(75.07 \%)$, followed by in the case of an election, I know about it through social media by $(74.78 \%)$, followed by I always take part in the parliamentary elections by $(71.88 \%)$, and lastly came fear of harm and security problems are the reason why I stay away from political participation by $(65.80 \%)$. 


\section{Study hypotheses test}

First hypothesis: "There are statistically significant differences at level $(\alpha=0.05)$ between the averages of the impact of social media on political participation among youth, due to the gender variable".

Table (5) The results of the t-test for two independent samples to examine the significance of the differences in the impact of social media on political participation among youth, due to the gender variable

\begin{tabular}{|c|c|c|c|c|c|c|c|c|}
\hline variable & gender & $\mathbf{N}$ & mean & S.d & d.f & $\begin{array}{c}(\mathbf{T}) \\
\text { Calculated }\end{array}$ & $\begin{array}{c}\text { (T) } \\
\text { tabular }\end{array}$ & sign \\
\hline \multirow{2}{*}{$\begin{array}{c}\text { political } \\
\text { participation }\end{array}$} & male & 64 & 3.78 & 0.410 & \multirow{2}{*}{113} & \multirow{2}{*}{1.98} & \multirow{2}{*}{3.331} & \multirow{2}{*}{$0.001 *$} \\
\hline & $\overline{\text { female }}$ & $\overline{51}$ & 3.60 & $\overline{0.472}$ & & & & \\
\hline
\end{tabular}

(s.d =standard deviation, $\mathrm{d} . \mathrm{f}=$ degree of freedom )

( $*$ Statistically significant at the level of significance $\alpha=0.05$ )

It is clear from the previous table that there are statistically significant differences at the level of significance $(\alpha=0.05)$ between the mean scores of males and that of females, in the of the impact of social media on political participation among youth, where the calculated value (T) equals (3.331), which is greater than the tabular (T) value (1.98). The arithmetic mean for males equals (3.78), which is greater than the arithmetic mean for females, (3.60). This indicates that there are differences in favor of males. Here, it is confirmed that there are statistically significant differences at level $(\alpha=0.05)$ between the averages of the impact of social media on political participation among youth, due to the gender variable.

The second hypothesis: There are statistically significant differences at the level $(\alpha=0.05)$ between the mean of the impact of social media on political participation among youth, due to academic year.

Table (6) the significance of the differences in the impact of social media on political participation among youth, due to for the academic year, using Test (one-way ANOVA)

\begin{tabular}{||c||c||c|c||c||c||c||}
\hline \hline variable & $\begin{array}{c}\text { sum of } \\
\text { squares }\end{array}$ & $\begin{array}{c}\text { Contrast } \\
\text { source }\end{array}$ & d.f & $\begin{array}{c}\text { mean } \\
\text { squares }\end{array}$ & $\begin{array}{c}\text { (F) } \\
\text { value }\end{array}$ & $\begin{array}{c}\text { semantic } \\
\text { level }\end{array}$ \\
\hline \hline \multirow{3}{*}{$\begin{array}{c}\text { political } \\
\text { participation }\end{array}$} & $\begin{array}{c}\text { between } \\
\text { groups }\end{array}$ & 0.277 & 4 & 0.069 & & \\
\cline { 2 - 4 } & $\begin{array}{c}\text { through } \\
\text { groups }\end{array}$ & 54.766 & 110 & 0.204 & 0.339 & 0.852 \\
\cline { 2 - 5 } & Total & 55.042 & 114 & & \\
\hline
\end{tabular}

(d.f $=$ degree of freedom) 
It is clear from the previous table that there are no statistically significant differences at the level $(\alpha=0.05)$ between the mean of the impact of social media on political participation among youth, due to the academic year, where the value of $(F)$ equals $(0.339)$. It is not statistically significant. This indicates that there are no statistically significant differences at the level $(\alpha=0.05)$ between the mean of the impact of social media on political participation among youth, due to the academic year.

The third hypothesis: There are statistically significant differences at the level $(\alpha=0.05)$ between the mean of the impact of social media on political participation among youth. This is due to the variable of the young's' political affiliation.

Table (7) The significance of the differences in the impact of social media on political participation among youth is due to the variable of the young's' political affiliation by using the (one-way ANOVA) test.

\begin{tabular}{|c|c|c|c|c|c|c|}
\hline variable & $\begin{array}{l}\text { sum of } \\
\text { squares }\end{array}$ & $\begin{array}{c}\text { Contrast } \\
\text { source }\end{array}$ & d.f & $\begin{array}{c}\text { mean } \\
\text { squares }\end{array}$ & $\begin{array}{c}(\mathrm{F}) \\
\text { value }\end{array}$ & $\begin{array}{c}\text { semantic } \\
\text { level }\end{array}$ \\
\hline \multirow{3}{*}{$\begin{array}{l}\text { political } \\
\text { affiliation }\end{array}$} & $\begin{array}{c}\text { between } \\
\text { groups }\end{array}$ & 2.880 & 4 & 0.720 & \multirow{3}{*}{3.669} & \multirow{3}{*}{$0.006^{*}$} \\
\hline & $\begin{array}{l}\text { through } \\
\text { groups }\end{array}$ & 52.162 & 110 & 0.195 & & \\
\hline & Total & 55.042 & 114 & & & \\
\hline
\end{tabular}

(d.f= degree of freedom )

(*Statistically significant at the level of significance $\alpha=0.05$ )

It is clear from the previous table that there are statistically significant differences at the level $(\alpha=0.05)$ between the mean of the impact of social media on political participation among youth due to the variable of political affiliation of the young, where the value of $(F)$ equals (3.669). It is statistically significant. This indicates that there are statistically significant differences at the level $(\alpha=0.05)$ between the mean of the impact of social media on political participation among youth due to the variable of political affiliation of the young. 
-In order to find out the source of the differences, a Scheffe's test was used for comparison afterwards.

Table (8) Scheffe test results compare between the means of the impact of social media on political participation among youth, according to the variable of political affiliation of the young.

\begin{tabular}{||c||c||c||c||c||}
\hline \hline political affiliation & $\begin{array}{c}\text { party } \\
\text { affiliation }\end{array}$ & independent & $\begin{array}{c}\text { affiliation Left- } \\
\text { wing opposition }\end{array}$ & $\begin{array}{c}\text { There is no } \\
\text { political } \\
\text { affiliation }\end{array}$ \\
\hline \hline party affiliation & & $0.175^{*}$ & 0.182 & 0.335 \\
\hline \hline independent & $* 389$ & & 0.007 & 0.159 \\
\hline \hline $\begin{array}{c}\text { affiliation Left- } \\
\text { wing opposition }\end{array}$ & & 0.214 & & 0.152 \\
\hline $\begin{array}{c}\text { There is no political } \\
\text { affiliation }\end{array}$ & & 0.207 & & \\
\hline
\end{tabular}

The previous table indicates that there are statistically significant differences concerning political participation among youth, between political participation (independent affiliation) and political participation (party affiliation), in favor of political participation (independent affiliation).

\section{Discussion of results}

- The results of the study confirmed that the mean age of youth (18) years reached the mean number of family members (4) individuals. The majority of them were males, with the majority of young people from the fourth year and the most used social media was Facebook. However, regarding family income level, the majority of the economic level was from middle-income families, with the political affiliation of youth as independent, and mobile phones as the social media usage tool. The average daily use of social media by youth was from two hours to less than four hours.

- The nature of the impact of social media on university youth and its reflection on their political participation are represented by: social networking sites providing a space to express opinion freely without a security threat, followed by social media as my primary source of information. Ranked last was their confidence in information received from social media. 
This is in agreement with Auskalniene (2012) about social media being more and more involved into the everyday communication practice and becoming one of the major political communication channels. This also agrees with the Network theory of "Manuel Castells" which confirmed that the network society is that society in which networks shape its social structures, as these networks are based on communication technologies. Through the nature of the social structure, the organizational hierarchies of human beings can be understood as manifested in experiences, knowledge, arts, language, housing, clothing, food, medicine, standards, production, distribution, relationship to others, and the power expressed in meaningful communication through culture.

- The extent of the prevalence of social media among university youth and its use in political participation are represented by: I always put my political opinion forward on social media, and this is followed by accepting criticism from others when discussing political matters. Ranked last is the fear of harm and security problems as the reasons why youth stay away from political participation.

This is in agreement with the study of Loader et al. (2014) about the role played by social media use in the processes by which young people become politically engaged. In addition, this agrees with the study of Hayes \& Carr (2014) that shows how social media may uniquely isolate and test communicative principles to advance our understanding of human-human and human-computer interaction. Furthermore, this coincides with the study of Vromenet al (2015) about how understanding young people's political engagement reveals important differences evident in young people's citizenship norms: between the dutiful allegiance to formal politics and their preference for online selfactualizing and discursive forms of political engagement and organizing.

- This confirms that there are statistically significant differences at level $(\alpha=0.05)$ between the averages of the impact of social media on political participation among youth, due to the gender variable in favor of males.

- There are no statistically significant differences at the level $(\alpha=0.05)$ between the mean of the impact of social media on political participation among youth, due to the academic year. 
- There are statistically significant differences at the level $(\alpha=0.05)$ between the mean of the impact of social media on political participation among youth, due to the variable of political affiliation of the young, in favor of independent affiliation.

\section{The study recommends supporting youth on political participation through the use of social media:}

- Paying attention to raising awareness of the importance of youth political participation and not being afraid to express their opinion through various media channels, including social media.

- Spreading the culture of political participation among youth through social media.

- Informing young people of their political rights and duties.

\section{References}

Allaste, Airi-Alina\& Cairns, David (2016). Youth Political Participation in a Transition Society, studies of transition states and societies journal, Vol 8, No 2.

Arshad, Saman\& Khurram, Sobia (2020. Can government's presence on social media stimulate citizens' online political participation? Investigating the influence of transparency, trust, and responsiveness, Government Information Quarterly, science direct, Elsevier journal, Volume 37, Issue 3.

Auskalniene, Lina (2012). Assessing Participation Online: Youth and Their Involvement in social media, information Mokslai / Information Sciences, Vol. 59.

Carr, Caleb T. \& Hayes Rebecca A. (6 Feb 2015). social media: Defining, Developing, and Divining, Atlantic Journal of Communication, Volume 23, Issue 1.

Castells, Manuel (2004). Informatics, Networks, and the Network Society: a Theoretical Blueprint, in: Manuel Castells (ed.), The Network Society: A Cross-cultural Perspective (Northampton, MA: Edward Elgar).

Dewing, Michael (2010). social media: An Introduction, Library of Parliament, Ottawa, Canada.

Gauthier, Madeleine (2010). The inadequacy of concepts: the rise of youth interest in civic participation in Quebec, Journal of Youth Studies, Volume 6, Issue 3.

Grossman, L. (2009). Iran Protests: Twitter, the medium of the movement. Time.Retrieved March 17, 2010, from http://www.time.com/time/ World/article/0, 8599, 1905125, 00.html

Harris, A. and Wyn, (2009). Young People's Politics and the Micro-Territories of the Local. Australian Journal of Political Science, 44 (2), 327-

Jamieso, Jamieson (2020). Political participation and European citizenship identity, Academia Accelerating the world's research, International Research Grant Program, U.S.A.

Li, Jennifer S. \& Barnett, Tracie A. \& Goodman, Elizabeth\& Wasserman, Richard C. and Kemper, Alex R., (January 2013). Approaches to the Prevention and Management of Childhood Obesity: The Role of Social Networks and the Use of social media and Related Electronic Technologies, Circulation Journal, Vol 127, Issue 2.

Loader, Brian D.\& Xenos, Michael\& Vromen, Ariadne (2014). The great equalizer? Patterns of social media use and youth political engagement in three advanced democracies, Information, Communication \& Society journal, Volume 17,Issue 2.

Loader, Brian D.\& Xenos, Michael\& Vromen, Ariadne (2014). The great equalizer? Patterns of social media use and youth political engagement in three advanced 
democracies, Information, Communication \& Society journal, Volume 17,Issue 2.

Matza, David \& Fares, Robert (1984). Position and Behavior Patterns of Youth, Handbook of Modern Sociology, Chicago, Rand Ncnally Company.

Mayfield, Thomas D. (2011). A Commander's Strategy for social media, for the Africa Center for Strategic Studies, From NDU Press, JFQ / issue 60, 1 st quarter.

Pew Research Center and Common Sense Media (2017). Report for Looking for 'Likes': Teens and Social Media Addiction, Orange, California. U.S.A.

Pleyers, Geoffrey (2020). Young people and alter-globalization: from disillusionment to a new culture of political participation, Academia Accelerating the world's research, International Research Grant Program, U.S.A.

Quintelier, Ellen\& van Deth, Jan W (2014). Supporting Democracy: Political Participation and Political Attitudes. Exploring Causality Using Panel Data, Political Studies Journal, Volume 62. Issue S1.

Rahimi, B. (2003). Cyberdissent: The Internet in Revolutionary Iran. Middle East Review of International Affairs, (7), (3).

Robinson, Joan (1953). The production function and the theory of capital, Review of Economic Studies, vol. 21, no. 2.

Schuster, Julia (2017). Invisible feminists? Social media and young women's political participation, Published online: $02 \quad$ May 2017, https://doi.org/10.1177/0032318713486474.

Seltzer, M. Mariam (1984). Youth Home Economics Agriculture and Third World Development, New York, the Free Press.

Vromen, Ariadne\&. Xenos, Michael A\& Loader, Brian (2015). Young people, social media and connective action: from organizational maintenance to everyday political talk, Journal of Youth Studies, Volume 18, Issue1.

Vromen, Ariadne\&. Xenos, Michael A\& Loader, Brian (2015). Young people, social media and connective action: from organizational maintenance to everyday political talk, Journal of Youth Studies, Volume 18, Issue1.

Zúñiga, H. Gil de\& Molyneux, Logan \& Zheng, Pei(2014). Social Media, Political Expression, and Political Participation: Panel Analysis of Lagged and Concurrent Relationships, Journal of Communication, Volume 64, Issue 4. 
